\title{
J(৫)
}

Received: 21.12.2019

\section{A Volga Bulgarian Classifier: A Historical and Areal Linguistic Study}

\section{Bir Volga Bulgar Ölçütü: Tarihî ve Bölgesel Bir Araştırma}

\author{
Klára AGYAGÁSI \\ University of Debrecen (Debrecen/Hungary) \\ E-mail: agyagasi.klara@arts.unideb.hu
}

In the Old Turkic period, the East Old Turkic variety produced written records, while the Oguric versions of West Old Turkic left oral sources from which data relevant to a given language state can be extracted. The author provides a historical and areal linguistic overview of Volga Bulgarian words meaning 'seed, grain, kernel', contemporary correspondences of which used as classifiers in the Volga-Kama region.

Key Words: classifiers, West Old Turkic derivational archaism, Volga Bulgarian dialects, Chuvash type phonetic criteria, Volga Bulgarian-Proto-Mari contacts. 


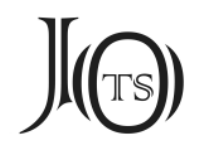

\section{Introduction}

Historical linguistic research into classifiers in Chuvash and its ancestor language, Volga Bulgarian, was prompted by research into the origin of Hungarian classifiers at K. É. KIss's suggestion. ${ }^{1}$

Hungarian has a nun common subtype of classifiers, that of what we had named "individual cataloguing classifiers", which characterize individuals and naturally occurring discrete units on the basis of quality, shape, or other typical and inherent features (e.g. egy fej káposzta 'a head of cabbage', egy szem mazsola 'one raisin', egy szál gyertya 'one candle', egy bokor krumpli 'one potato'). ${ }^{2}$ The Hungarian classifiers occur in a Num-Cl-N pattern where $\mathrm{Cl}$ is obligatorily a nominative stemform, and their most important characteristics are that (1) they cannot be used without a numeral, (2) they can be optionally deleted without change of meaning, and (3) no abstract noun can be used as the noun in the pattern (Agyagási-Dékány 2019).

In linguistic research into Chuvash, identifying classifiers has just recently begun (Sergeev 2017: 233), and individual classifiers do not figure among the identified subtypes as yet. Our comparative Old Turkic-Ancient Hungarian investigation focused specifically on the individual classifier pattern which is so prevalent in Hungarian but which has not yet been found in Chuvash. In AgyagásiDékány (2019), we identified two Chuvash words (pěrčě 'kernel', tuna 'stem') in classifier function and, analysing forms of these nouns used by native speakers, we traced and posited their Volga Bulgarian and Western Old Turkic/Ogur ${ }^{3}$

\footnotetext{
1 The first findings of the joint research by É. DÉKÁNY and myself were presented in our talk at the 2018 conference in the Linguistic Theory and Contact Linguistics [Nyelvelmélet és Kontaktológia] conference series initiated by K. É. KIss.

2 Except in the case of a head of cabbage, English equivalents do not offer a parallel structure of the Hungarian phrases where a classifier is used to refer to individual instances of the noun in question. The Hungarian classifiers used in the examples are literally 'one kernel of raisin', 'one stem of candle', and 'one bush of potatoes'.

3 In the history of Turkic languages, the split between the Oguz and Ogur branches occurred at the end of the Ancient Turkic period. The groups speaking Ogur languages (the Ogurs, Bulgarians, Avars, and Khazars) appeared in Europe in the 5th century, on the southern steppes of the Eastern European area. Their varieties comprised the Old Turkic dialect formed on an areal basis between the 5th and 13th centuries. Beginning with the 11th century, some Kipchak dialects were also added to this old
} 


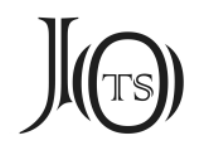

origin. The word pěrče 'kernel' has rich variation in its phonetics and derivation regionally. The word geographic investigation described below aimed to identify Western Old Turkic/Ogur archaisms preserved by Volga Bulgarian dialects, which demonstrate some general characteristics of extinct languages and provide evidence pointing to the fact that the group of words in question is from an old, pre-Chuvash layer of the lexicon.

\section{The history of the Chuvash word for 'kernel'}

The standard form of the examined Chuvash word is perrče (cf. Skvorcov), which goes back to the early Western Old Turkic form *bürtik4 ${ }^{4}$. It is the causative $\{-\mathrm{t}-\}$ marked form of the verb bür- bearing the derivational suffix $\{-\mathrm{Ok}\}$ participating in forming nouns out of verbs, cf. Eastern Old Turkic bür- 'stjagivat', zatjagivat' (s obrazovanijem skladok)', bürt- 'zastavit' stjanut', slodcit' (Nadelyayev et al. 1969: 132-33). For more about the Old Turkic $\{-0 k\}$ derivational suffix, see Erdal 1991: 172-223.

As is attested in the Hungarian lexical borrowings from Western Old Turkic (cf. Róna-Tas-Berta 2011: 1076), the early Old Turkic form *bürtik had changed in one of two ways in Western Old Turkic: the word final voiceless guttural was preserved unchanged, or it became voiced and underwent secondary voicing and spirantization (bürtik > bürtig > bürtiү), with the spirant disappearing as early as

Turkic dialect. No written sources of Western Old Turkic have been preserved, whereas the most important oral source of it is the corpus of Old Turkic loanwords in Proto-Hungarian (Róna-Tas-Berta 2011). Groups speaking a dialect that goes back to the Oguz variety of Eastern Old Turkic lived in Inner Asia and Southern Siberia at around the same time. Eastern Old Turkic has a rich collection of written sources. Modern Chuvash is the only descendant language of the Ogur branch. The ancestors of its speakers left the Khazar Empire in the 8th century and migrated to the region at the confluence of the Volga and Kama rivers, where they founded the Volga Bulgarian Empire in the 10th century. In the central Volga region three Volga Bulgarian dialects developed, and Chuvash is the descendant of the 3rd dialect of Volga Bulgarian (Agyagási 2019: 160-183). Sources refer to it as a separate language beginning with 1508 .

4 Parallels between Chuvash and Common Turkic and their occurrence in Mari regional dialects have been pointed out by Fedotov (1996/I: 423-424). 


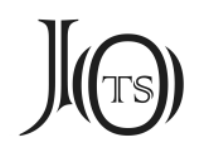

the first third of the Old Turkic period. ${ }^{5}$ The standard Chuvash form reflects the latter, but the same change is reflected in Chuvash dialectal forms from the Anatri (A) and Viryal (V) dialects: A pěrčĕe, Szp. pörč̌̆o 'kernel, grain or cereal' (Paasonen 1974: 97), pěrčě (Simbirsk) 'zerno, zernıško; kaplja'; (Samara) 'jagodka, kroška, krupinka, snedcinka' (Buinsk) ‘volokno', V pörčŏ 'zerno' (Ašmarin 19281950/10: 236).

At the same time, the preservation of the word final guttural in the Western Old Turkic form *bürtik is also apparent in variant forms in the Anatri and Viryal dialects: perč̌̌k, pớrčŏk 'kernel' (Ašmarin 1928-1950/10: 237). This means that in Chuvash the reflexes of two different earlier Western old Turkic regional variants $^{6}$ are present. This, however, is not the extent of the regional variants of Western Old Turkic *bürtik.

As is well known, some of the population that spoke mostly the Ogur varieties of Western old Turkic left the Khazar empire in the 8th century and, in several waves, migrated north to the region of the confluence of the Volga and Kama rivers (Agyagási 2019: 1-2) and established an empire there in the early 10th century. The Volga Bulgarians populated three sections of the region separated by the rivers. In these sections of the region, three Volga Bulgarian dialects of Ogur origin developed, which are different from each other in the details of the temporal oppositions of their vowel systems (Agyagási 2019: 160-183). From the point of view of the later change of the Western Old Turkic form *bürtik, dialects 1 and 3 of Volga Bulgarian ${ }^{7}$ (the latter is the immediate precursor of Chuvash) may be affected, since in this word no long vowels occur, which are characteristics of dialect 2 .

5 This type of change in gutturals was treated as a Chuvash kind of criterion in Turkic studies in Hungary when examining Turkic loanwords in Hungarian. Later, it was excluded from this category since it represents a parallel development of Hungarian and Chuvash (Agyagási 2013: 164).

6 Róna-Tas 1998, identified the Western Old Turkic language area with the region of the Eastern European steppe in the period between the 5 th and 13 centuries.

7 Since this dialect became a substrate language following the Mongol Invasion and then became extinct, no endonym for it was preserved. The identification of Volga Bulgarian by numbers is thus a necessity that follows from this situation. 


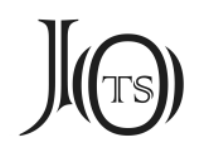

The dialect forms of PAASONEN and AŠMARIN contain reduced vowels in both syllables: in the Anatri dialect, reduced vowels are front unrounded vowels, whereas in Viryal both are front rounded. Such a representation of the Old Turkic high vowels fits fully the changes that took place in dialect 3 of Volga Bulgarian in the early Middle Chuvash period: following a Proto-Mari pattern, the reduction of high vowels occurred as a result of partial code copying.The reduced vowels appeared first in the second syllable, as allophones of the short vowels, and later the vowel height became phonemic, and all originally high vowels of words became reduced (Agyagási 2019: 196-220). The cited forms demonstrate that in the change of the form *bürtik a levelling in the labialization of the vowel structure of the word occurred before the modern Chuvash period. This levelling could have happened only in Middle Chuvash, after the /ti/ > /či/ change occurred in the word medial position. The history of the forms pěrčĕ, perrčěk, V pö̌rčö, and pörčŏk, generally widespread in the Chuvash language area, can be reconstructed as follows:

WOT *bürtik 'kernel' > VB *bürtik > VB3 *pürtïk > *pürčlk > Middle Chuv. *pürčük > *pürčǘk > V pörčŏŏk A pěrčěk 'id.'

WOT *bürtik 'kernel' > *bürtiү > VB *bürti > VB3 *pürtĭ > * pürčlı > Middle Chuv.

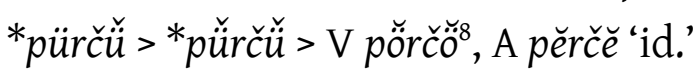

In dialect 3 of Volga Bulgarian the Western Old Turkic form *bürti also underwent another type of levelling, to unrounding, as is evidenced by A. AHLQVIST's data collected in 1856 in the Viryal language area, showing only unrounded pírcce [pĕrčě] 'zerno' ( * * pirči < *birti < WOT *bürti) (Ahlqvist 2008: 24).

The Anatri dialect of the Buinsk region preserved two further forms of the word perrčě : pěrčěn 'zernıškami' (Ašmarin 1928-1950/10: 237) and pěrčěš 'zerno, nebol'šaja čast' (Ašmarin 1928-1950/10: 238). Both are morphological archaisms. The word final $\{-n\}$ of perrčĕn is an archaic instrumental case suffix of Old Turkic. See Erdal 2004:175-77. Words with this suffix had adverbial usage already in Eastern Old Turkic, but the lexemes of Western Old Turkic origin in Chuvash where

8 The Viryal word was attested already in Damaskin's 1785 dictionary as pjur'ču 'zerno'. 


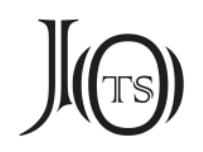

it was preserved (including pěrčĕn 'kernel by kernel' < WOT *bürtin), are exclusively adverbs (cf. Levitskaja 1976: 27). The word final $\{-\check{s}\}$ morpheme of the form perrčěs is the reflex of the Ogur phonological variant of the archaic Western old Turkic 3rd person possessive marker $\{-$ si\} (WOT *bürtisi >> Chuv. A pěrčěs). This person marker was preserved in Chuvash only in kinship terms and some pronouns, reinterpreted as a derivational formant (Levitskaja 1976: 15, 35).

\section{The occurrences of Western Old Turkic * bürtik 'kernel' in the Volga Bulgarian substrate}

The variant of the Western Old Turkic word * bürti developed in Volga Bulgarian occurs also in dialect 1 of Volga Bulgarian. Contact linguistic works demonstrate that, in this dialect, the reduction of high vowels happened already in the late old Turkic period. This process affected the vowels in the initial syllable, since it was based on the phonetic difference of the unstressed : stressed position (Agyagási 2019: 197-199). Examples show that high vowels in initial syllables were reduced by the beginning of Chuvash-Mari language contact to such an extent that they produced a schwa sound quality demonstrating a single distinctive feature (front-back opposition). This is also attested in the later Volga Bulgarian pattern of change of WOT *bürti ${ }^{9}$ (VB1*pirči < * birti < WOT *bürti), although not in the Chuvash language area but in Mari dialects: P B M UJ C Č pârče,

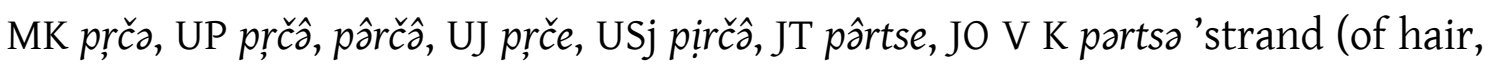
thread, straw, grass); kernel (of wheat; bead); drop (of rain, snow)' (Beke 2000: 1838). Since the Volga Bulgarian word is widespread in the entire Mari language area ${ }^{10}$ it is reasonable to regard the borrowing as the result of contact between late Ancient Hungarian and the VB1 dialect, as well as a result of interference through shift from the substrate of the Volga Bulgarian minority that assimilated into the Mari speaker community.

\footnotetext{
9 As is clear from BEKE's dictionary, the schwa of the first syllable has gone to nearly zero by now in several locations of data collection. BEKE used the symbol $r$ for the syllabic form in place of the first syllable vowel in his dictionary.

10 BEKE's data are also independently confirmed by fieldwork data collected by Finnish researchers; $\mathrm{cf}$. Moisio \& Saarinen (2008: 582).
} 


\title{
J(৫)
}

If we project the forms meaning 'kernel' into a map, we can conclude that the reflexes of the Volga Bulgarian dialectal form *bürti going back to WOT *bürtik were widespread in the dialects of both Chuvash and Mari, while the variants derived in $\{-n\}$ and $\{-5$ s $\}$ are limited to the Chuvash language area. The Volga Bulgarian precursor of Chuvash, then, preserved a group of three elements of old, Western Old Turkic in its lexicon, of which only *bürti and its phonetic variants were distinct in classifier function, since the other two forms were not nominative stem forms - as could be expected on the basis of the copy that entered Hungarian. This word and its variants participated in the pattern of individual classifiers that served as a model for other non-dominant Volga region languages in copying classifier constructions (Agyagási-Dékány 2019: 60-64). The regional dialects of the Mari language did not only copy the Num-Cl-N pattern of the nonChuvash type other dialect of Volga Bulgarian but also the Volga Bulgarian lexeme of classifier function, together with the pattern.

The classifier function of the word meaning 'kernel' developed very likely already in the early dialects of Western Old Turkic/Ogur, prior to the 10th century. Only such an early timeline can explain the fact that the characteristics of the classifier pattern are completely identical in Chuvash and the Finno-Ugric languages that originally did not have classifiers but developed their own individual classifier patterns by copying the Ogur or Volga Bulgarian pattern of the Num-Cl-N construction of Western Old Turkic.

\author{
Abbreviations \\ $\mathrm{A}=$ Anatri dialect. \\ Chuv. $=$ Chuvash . \\ $\mathrm{V}=$ Viryal dialect. \\ $\mathrm{VB}=$ The Volga Bulgarian. \\ VB1 = The Ist Volga Bulgarian type of the West Old Turkic \\ VB3 = The IIIrd Volga Bulgarian type of the West Old Turkic. \\ WOT $=$ West Old Turkic .
}




\section{J(G)}

\section{References}

AGYAGÁsI, K. \& É. DÉKÁNY (2019). Ótörök hatás a magyar osztályozószók kialakulásában, Nyelvelmélet és kontaktológia 4, Eds. É. Kiss KATALIN et al., PPKE BTK, Piliscsaba: 41-75.

AGYAGÁsI, K. (2013). "Nyugati ótörök és magyar kapcsolatok: tanulságok az ogur hangtörténet számára", Nyelvelmélet és kontaktológia 2, Eds. K. AGYAGÁSI et al., PPKE BTK, Piliscsaba: 155-172.

AgYAGÁsI, K. (2019). Chuvash Historical Phonetics, an Areal Linguistic Study, with an Appendix on the Role of Proto-Mari in the History of Chuvash Vocalism, Wiesbaden: Harrassowitz Verlag.

AHLQvist, A. (2008). Tsçhuwasçhiska I, Tschuwaschischer Nachlass von A. AHLQvist. Hrsg. von K. AgYagÁsI \& E. WINKLER, Debrecen: Kossuth Egyetemi Kiadó.

AŠMARIN, N. İ. (1928-1950). Slovar' čuvašskogo jazyka I-XVII, Čeboksary: İzdatel'stvo Russika.

BEKE, Ö. (2000). Mari nyelvjárási szótár (Tscheremissisches Dialektwörterbuch) VI, Hrsg. von J. PUsZTAY, Savariae: Berzsenyi Dániel Tanárképző Főiskola.

ERDAL, M. (1991). Old Turkic Word Formation, a Functional Approach to the Lexicon I-II, Wiesbaden: Harrassowitz Verlag.

ERDAL, M. (2004). A Grammar of Old Turkic, Leiden-Boston: Brill.

FEDotov, M. R. (1996). Etimologičeskij slovar' čuvaškogo jazyka I-II, Čeboksary: Čuvaškij Gosudarstvennyj İnstitut Gumanitarnyx Nauk.

LEVITSKAJA, L. S. (1976). İstoričeskaja morfologija čuvaškogo jazyka, Moskva: Nauka.

MoISIO, A. \& S. SAARINEN (2008). Tscheremissisches Wörterbuch, Helsinki: Lexika Societatis Fenno-Ugricae.

NADELYAYEV, V. M. et al. (1969). Drevnetjurkskij slovar', Leningrad: Institut Jazykoznanija, Akademija Nauk SSSR.

PaAsonen, H. (1974). Tschuwaschisches Wörterverzeichnis, eingeleitet von A. RóNA-TAS, Szeged: Studia Uralo-Altaica.

RóNA-TAS, A. \& B. ÁRPÁD (2011). West Old Turkic: Turkic Loanwords in Hungarian I-II, Wiesbaden: Harrassowitz Verlag. 


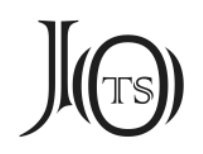

RónA-TAS, A. (1998). "Western Old Turkic", the Mainz Meeting. Proceedings of the Seventh International Conference on Turkish Linguistics, Ed. By L. JOHANSON in cooperation with É. Á. CsATó et al., Harrassowitz Verlag, Wiesbaden: 619-626.

SEREBRENNIKOv, B. A. (1956). Marijsko-russkij slovar', Moskva: Gosudarstvennoje İzdatel'stvo İnostrannıx i Natsional'nıx Slovarej.

SERGEEV, V. I. (2017). Morfologija čuvašskogo jazyka, Čeboksary: Čuvaškij Gosudarstvennyj İnstitut Gumanitarnyx Nauk.

SKvorcov, M. I. (1982). Čuvašsko-russkij slovar', Moskva: İzdatel'stvo “Russkij Jazyk". 